\title{
Exogenous Foliar Melatonin Improves Cotton (Gossypium Hirsutum L.) Physio-Biochemical Characteristics Under the Synergetic Effects of Low Temperature and Salinity Stress
}

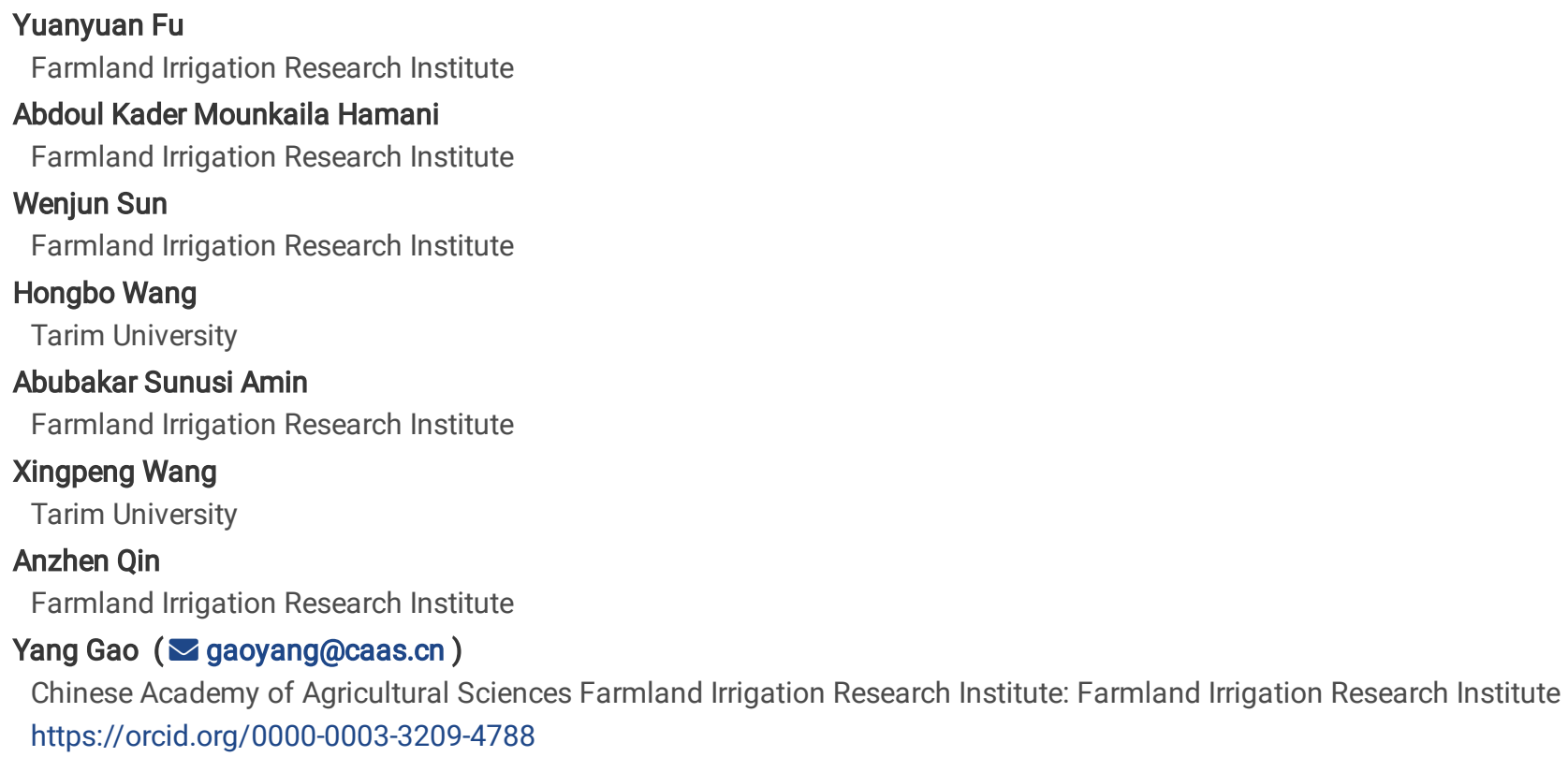

\section{Research Article}

Keywords: cotton seedlings, ion homeostasis, melatonin, membrane damage, low temperature, salinity

Posted Date: November 11th, 2021

DOI: https://doi.org/10.21203/rs.3.rs-1045095/v1

License: @ (i) This work is licensed under a Creative Commons Attribution 4.0 International License. Read Full License 


\section{Abstract}

Low temperature and soil salinization during cotton sowing and seedling have adverse effects on cotton productivity. Finding an alternative for reducing the low temperature and salt induced damages during the seedling stage of cotton is a challenge for agricultural researchers nowadays. The physiological mechanism of exogenously applied melatonin (MT) on cotton seedlings under low temperature and salt stress is still unclear. The experiment in a phytotron was comprised with two temperature levels of $15^{\circ} \mathrm{C}$ and $25^{\circ} \mathrm{C}$, and $5 \mathrm{MT}$ treatments of 0,50 , $100,150,200 \mu \mathrm{M}$, and two salinity levels of 0 and $150 \mathrm{mM} \mathrm{NaCl}$ stress. Compared with the control treatments (non-salinity stress under $15^{\circ} \mathrm{C}$ and $25^{\circ} \mathrm{C}$ ), the coupled stress of salt and low temperature reduced cotton seedlings' biomass and net photosynthetic rate $\left(P_{n}\right)$, aggravated the membrane damage, reduced the potassium $\left(\mathrm{K}^{+}\right)$content and increased the sodium $\left(\mathrm{Na}^{+}\right)$accumulation in the leaves and roots.

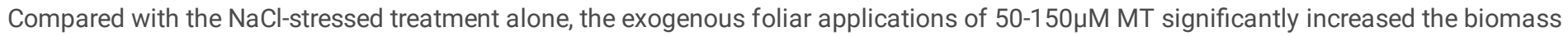
and gas exchange parameters of cotton seedlings under the coupled salt and low temperature stress conditions. The exogenously applied

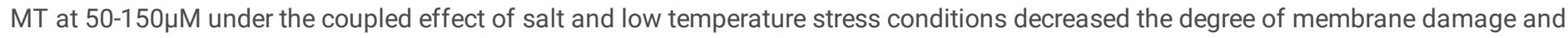
regulated the activities of the protective enzymes, ion homeostasis, ion transport and absorption of cotton seedlings. The pairwise correlation analysis of each parameter by MT shows that the parameters with higher correlation with $\mathrm{MT}$ at $15^{\circ} \mathrm{C}$ are mainly malondialdehyde (MDA), peroxidase (POD), and catalase (CAT). The most relevant parameters at $25^{\circ} \mathrm{C}$ are $\mathrm{K}^{+}$concentration in leaves $\left(\mathrm{K}^{+}-\mathrm{L}\right), \mathrm{K}^{+}$concentration in root $\left(\mathrm{K}^{+}-\mathrm{R}\right), \mathrm{Na}^{+}$concentration in leaves $\left(\mathrm{Na}^{+}-\mathrm{L}\right), \mathrm{Na}^{+}$concentration in root $\left(\mathrm{Na}^{+}-\mathrm{R}\right), \mathrm{Na}^{+}$uptake in-root surface ( $\mathrm{Na}^{+}$-uptake), $\mathrm{K}^{+}$ion translocation $\left(\mathrm{K}^{+}\right.$-translocation). Stepwise linear regression of the above parameters found that $\mathrm{MT}$ is more related to $\mathrm{MDA}$ at $15^{\circ} \mathrm{C}$, and $\mathrm{MT}$ is more related to $\mathrm{Na}^{+}-\mathrm{L}$ at $25^{\circ} \mathrm{C}$.

\section{Introduction}

Plants are often exposed to various environmental stresses, including drought, heavy-metal contamination, heat stress, low temperature, and soil salinization. Among these stresses, salinity and low temperature are important abiotic factors that are consequently associated with limited plant growth and productivity (Ashraf and Foolad, 2007;Mishra et al., 2016;Sun et al., 2017;Naing and Kim, 2021). Moreover, over 50\% of the world's arable land is predicted to be affected by salinity by 2050 (Demiral and Türkan, 2006;Saeed et al., 2021), while 15\% of the suitable agricultural areas are affected by temperature stress worldwide (Çiçek and Çakırlar, 2008). Soil salinization is often accompanied by temperature stress because changes in ambient temperature are more frequent than changes in other abiotic factors. On the other hand, changes in ambient temperature rapidly aggravates other environmental stresses, including salinity (Ashraf and Foolad, 2007;Çiçek and Çakırlar, 2008).

Salinity caused by $\mathrm{NaCl}$ has recently become a focus in environmental research investigations. $\mathrm{NaCl}$-associated salinity leads to a wide range of changes in plant metabolism (Dong et al., 2014;Hamani et al., 2021). An increasing $\mathrm{NaCl}$ concentration affects plants in several ways. It causes nutrient deficiencies, osmotic stress and specific ion toxicity, thereby affecting several physiological mechanisms involved in plant metabolism (Munns, 2002). Salt stress affects a range of important mechanisms, including photosynthesis, energy and lipid metabolism and protein synthesis (Parida and Das, 2005). Low temperature stress generally affects plant growth and induces reactive oxygen species production, leading to damage of cell membrane structure (Yan et al., 2021). Previous studies reported that low temperature stress rapidly increases antioxidants activities, such as superoxide dismutase (SOD), peroxidase (POD), and catalase (CAT) (Airaki et al., 2012; Sun et al., 2017). Lichtenthaler et al. (2005) founded that the photosynthetic functions and physicochemical properties of thylakoid membranes are directly or indirectly affected by temperature and salt stresses.

Melatonin (N-acetyl-5-methoxytryptamine), which was initially identified and isolated from the pineal glands of cows, is an important multifunctional hormone that involved in a range of animal's physiological processes modulation, such as sleep (Zhao et al., 2022), immunity and reproduction (Arnao and Hernández-Ruiz, 2006;Calvo et al., 2013), circadian rhythm and antioxidant activity (Zhan et al., 2021). Melatonin was discovered for the first time in 1995 in vascular plants as an indoleamine hormone (Hattori et al., 1995). Melatonin plays a key role plant growth and development by promoting root growth and seedling's biomass accumulation, like auxin in function (Byeon and Back, 2014;Hardeland, 2016). Several researches revealed the importance of melatonin in mitigating biotic and abiotic stresses (Liang et al., 2015; Shi et al., 2015;Sharma et al., 2020). Known as an antioxidant and free radical scavenger, exogenously applied melatonin improved plants' resistance to biotic and abiotic stresses, which confers to plant stress resistance by enhancing photosynthesis, ion homeostasis and antioxidant enzymes activities (Bajwa et al., 2014;Zhang and Zhang, 2014). Exogenous foliar application of melatonin is involved in numerous physiological processes to improve plant resistance to salinity stress (Zhao et al., 2022). Recent study demonstrated that exogenously applied melatonin could sustain a high photosynthetic rate in tea plants, which enhances salt tolerance through its effects on antioxidant response against environmental stress (Li et al., 2019). Exogenous application of melatonin under sat stress showed alleviating effects on horticultural crops, such as increase in primary root length and antioxidant activity in sunflower (Mukherjee et al., 2014), increase in net photosynthetic rate and stomatal conductance in tomato (Ding et al., 2017), and improving photosynthetic efficiency, endogenous 
melatonin content and ion homeostasis in upland cotton (Shen et al., 2021). On the other hand, exogenous application of melatonin was found to improve the resistance capacity of horticultural crops to low temperature stress by, increasing photosynthetic rate, antioxidant activity, and decreasing MDA content in tea plants (Li et al., 2018), increasing endogenous melatonin content, antioxidant activity and decreasing malondialdehyde (MDA) content in Bermudagrass (Fan et al., 2015), and increasing photosynthetic carbon assimilation, activities of antioxidant enzymes, levels of non-enzymatic antioxidants and decreasing in cold damage on cell membranes accumulation of ROS in tomato (Ding et al., 2017).

Cotton is the world's most important natural textile fiber with an incredible economical value and is considered as the backbone of the textile industry. Despite the capacity of cotton plants to relatively tolerate environmental stress, exposure to high stress condition could negatively affect cotton growth, development, and ultimately yield (Xie et al., 2015;Hamani et al., 2020). For cotton grown in salty soils in arid/semiarid region, cotton seedlings often suffer environmental stress of low temperature and salinity. Therefore, several investigations have aroused keen interest for improving cotton resilience. Previous studies revealed mechanism of exogenous melatonin on crop resilience improvement under alone stress of salinity and low temperature, while there was little information on the effects of exogenous melatonin on crop performance under coupled low temperature and $\mathrm{NaCl}$-stressed. Therefore, the main purpose of this study was to determine the physiological and biochemical responses of low temperature and $\mathrm{NaCl}$-stressed cotton seedlings sprayed with exogenous melatonin.

\section{Materials And Methods}

\subsection{Plant materials}

The cotton variety, Xinluzhong37, was purchased from Tahe Seed Industry Co., Ltd., Alar City. It is a mid-early maturing upland cotton variety with a growth period of about 140 days. Melatonin $(\mathrm{MT})$, sodium chloride $(\mathrm{NaCl})$, sodium sulfate $\left(\mathrm{Na}_{2} \mathrm{SO}_{4}\right)$ and other chemical reagents are all analytically pure, purchased from Beijing Soleibao and Sinopharm Chemical Reagent Co., Ltd.

\subsection{Experimental design}

The experiment was carried out in a phytotron in the Xinxiang Comprehensive Experimental Station of Chinese Academy of Agricultural Sciences $\left(35.09^{\circ} \mathrm{N}, 113.48^{\circ} \mathrm{E}\right.$ and altitude $\left.81 \mathrm{~m}\right)$. The humidity of the climate room is $40-50 \%$, the photoperiod is $12 \mathrm{~h}$, the light intensity is 600 $\mu \mathrm{mol} \mathrm{m} \mathrm{m}^{-2} \mathrm{~s}^{-1}$ (lighting is provided by LED lights), and the temperature is controlled according to the experimental design. The experimental design is shown in Table 1.

Table 1

The detailed experimental treatments

\begin{tabular}{|llll|}
\hline Temperature & Treatment Label & $\mathrm{NaCl}$ Dose $(\mathrm{mM})$ & $\mathrm{MT}$ Dose $(\mu \mathrm{M})$ \\
\hline $15^{\circ} \mathrm{C}$ & $\mathrm{CK}$ & 0 & 0 \\
\cline { 2 - 4 } & 0 & 150 & 0 \\
& 50 & 150 & 50 \\
\hline $25^{\circ} \mathrm{C}$ & 150 & 150 & 150 \\
& 250 & 150 & 250 \\
& $\mathrm{CK}$ & 0 & 0 \\
\hline & 0 & 150 & 0 \\
& 50 & 150 & 50 \\
& 150 & 150 & 150 \\
\hline & 250 & 150 & 250 \\
\hline
\end{tabular}


Table 2

Response of antioxidant enzymes activities to MT in cotton seedlings under low temperature and salt stress

\begin{tabular}{|c|c|c|c|c|c|c|}
\hline \multirow{3}{*}{ Treatment } & \multicolumn{6}{|c|}{ Antioxidant enzymes activities in leaf tissues } \\
\hline & \multicolumn{2}{|l|}{$\mathrm{SOD} / \mathrm{U} \times \mathrm{g}^{-1} \times \mathrm{FW}$} & \multicolumn{2}{|l|}{$\mathrm{POD} / \times \mathrm{g}^{-1} \times \mathrm{FW}$} & \multicolumn{2}{|c|}{$\mathrm{CAT} / \mathrm{U} \times \mathrm{g}^{-1} \times \mathrm{FW}$} \\
\hline & $15^{\circ} \mathrm{C}$ & $25^{\circ} \mathrm{C}$ & $15^{\circ} \mathrm{C}$ & $25^{\circ} \mathrm{C}$ & $15^{\circ} \mathrm{C}$ & $25^{\circ} \mathrm{C}$ \\
\hline $\mathrm{CK}$ & $67.32 \pm 1.69 \mathrm{~cd}$ & $108.32 \pm 3.73 b$ & $13.32 \pm 1.24 \mathrm{a}$ & $7.38 \pm 0.20 b$ & $2.46 \pm 1.07 \mathrm{a}$ & $0.01 \pm 0.00 \mathrm{~b}$ \\
\hline $0 \mu \mathrm{M}$ & $69.27 \pm 4.65 \mathrm{~cd}$ & $78.52 \pm 4.09 \mathrm{c}$ & $4.38 \pm 0.27$ de & $5.09 \pm 0.27 \mathrm{~cd}$ & $0.11 \pm 0.01 b$ & $0.02 \pm 0.00 \mathrm{~b}$ \\
\hline $50 \mu \mathrm{M}$ & $147.18 \pm 2.23 \mathrm{a}$ & $45.32 \pm 4.33 \mathrm{f}$ & $5.17 \pm 0.07 \mathrm{~cd}$ & $5.95 \pm 0.74 \mathrm{c}$ & $0.03 \pm 0.01 b$ & $0.07 \pm 0.01 b$ \\
\hline $100 \mu \mathrm{M}$ & $137.57 \pm 22.54 \mathrm{a}$ & $51.96 \pm 1.09$ ef & $4.46 \pm 0.36 \mathrm{de}$ & $3.55 \pm 0.20$ ef & $0.04 \pm 0.01 \mathrm{~b}$ & $0.02 \pm 0.00 \mathrm{~b}$ \\
\hline $150 \mu \mathrm{M}$ & $140.41 \pm 5.72 \mathrm{a}$ & $58.09 \pm 2.41 \mathrm{def}$ & $4.45 \pm 0.31 \mathrm{de}$ & $3.79 \pm 0.18$ ef & $0.04 \pm 0.01 b$ & $0.02 \pm 0.01 b$ \\
\hline $200 \mu \mathrm{M}$ & $101.91 \pm 7.56 b$ & $63.78 \pm 5.69 \mathrm{de}$ & $3.14 \pm 0.11 \mathrm{f}$ & $3.95 \pm 0.39$ ef & $0.03 \pm 0.01 b$ & $0.04 \pm 0.00 \mathrm{~b}$ \\
\hline Temp & $11.79 \star \star$ & & 1.43 & & $29.48 * \star$ & \\
\hline MT & 2.60 & & $1.46^{\star \star}$ & & $20.29 \star \star$ & \\
\hline Temp×MT & 1.35 & & $9.90 * *$ & & $33.43 * \star$ & \\
\hline
\end{tabular}

Uniform size and plump cotton seeds were selected, disinfected with 1000 times' diluted solution of carbendazim, and rinsed with deionized water after 30 minutes. The sterilized cotton seeds were sown at a depth of $2 \mathrm{~cm}$ in PVC pots (diameter $6 \mathrm{~cm}$, height $24 \mathrm{~cm}$ ) containing $780 \mathrm{~g}$ of fine sand (sand was sterilized by high temperature). After sowing, the PVC pots were cover with an opaque shading board to keep the surface of the sand moist and facilitate the germination of seeds. For germination, the PVC pots were placed in a phytotron with a day/night temperature of $25 / 20^{\circ} \mathrm{C}$. After the seeds germinated, the shading was removed from the pots. When the seedlings grow to 1 true leaf, seedlings were watered with $1 / 2$ Hoagland nutrient solution (major elements: $118 \mathrm{mg} \mathrm{L}^{-1} \mathrm{Ca}\left(\mathrm{NO}_{3}\right) 24 \mathrm{H}_{2} \mathrm{O}, 506 \mathrm{mg} \mathrm{L}^{-1} \mathrm{KNO}_{3}, 136 \mathrm{mg} \mathrm{L}^{-1}$ $\mathrm{KH}_{2} \mathrm{PO}_{4}, 693 \mathrm{mg} \mathrm{L}^{-1} \mathrm{MgSO}_{4} 7 \mathrm{H}_{2} \mathrm{O}$ and trace elements: $2.86 \mathrm{mg} \mathrm{L}^{-1} \mathrm{H}_{3} \mathrm{BO}_{3}, 1.55 \mathrm{mg} \mathrm{L}^{-1} \mathrm{MnSO}_{4} \mathrm{H}_{2} 0,0.22 \mathrm{mg} \mathrm{L}^{-1} \mathrm{ZnSO}_{4} 7 \mathrm{H}_{2} \mathrm{O}, 0.09 \mathrm{mg} \mathrm{L}^{-1}$ $\mathrm{CuSO}_{4} 4 \mathrm{H}_{2} \mathrm{O}, 24 \mathrm{mg} \mathrm{L}^{-1} \mathrm{Na}_{2}$ FeEDTA) (Hamani et al., 2021). The pH of the nutrient solution is between 5.8 and 6.2 , each pot is watered every 5 days with about $80 \mathrm{ml}$ of the $1 / 2$ Hoagland solution. When the seedlings grown to two leaves and one heart leaf, they were randomly divided into groups for starting the salt and temperature treatments. The cotton seedlings treated at room temperature $\left(25^{\circ} \mathrm{C}\right)$ and low temperature $\left(15^{\circ} \mathrm{C}\right)$ were placed in phytotrons with day/night temperatures of $25 / 18^{\circ} \mathrm{C}$ and $15 / 8^{\circ} \mathrm{C}$, respectively. On the $1 \mathrm{st}$, 4 th, and 9 th day under the temperature treatment, seedlings were irrigated with $150 \mathrm{mmol} \mathrm{L}{ }^{-1}$ salt water $\left(\mathrm{NaCl}: \mathrm{Na}_{2} \mathrm{SO}_{4}=9: 1\right)$ in the morning. Every day after turning off the lights, different concentrations of $\operatorname{MT}\left(0,50,100,150,200 \mu \mathrm{mol} \mathrm{L}^{-1}\right)$ were sprayed on the upper surface of the leaves of salt and low temperature-stressed cotton seedlings. On the 10th day, the fully expanded leaves were sampled for the measurement of various indicators.

\subsection{Measurements}

\subsubsection{Determination of gas exchange parameters}

The LI-6400XT photosynthesis measuring system (Licor, USA) was used to measure, the net photosynthetic rate $\left(P_{n}\right)$, stomatal conductance $\left(g_{s}\right)$ intercellular carbon dioxide concentration $\left(C_{i}\right)$, and transpiration rate $\left(T_{r}\right)$ of the fully expanded leaves of cotton seedlings between 9:00$11: 00$ in the morning. For the gas exchange parameters measurements, 3 plants were randomly selected from each treatment, the red and

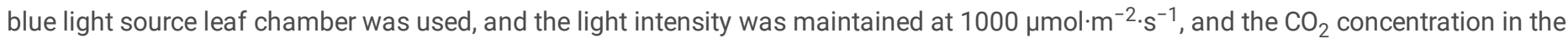

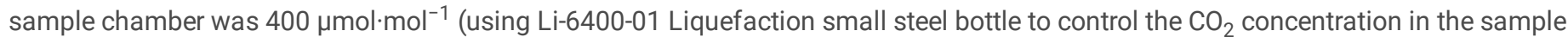
chamber), block temperature is $25^{\circ} \mathrm{C}$, and airflow is $500 \mu \mathrm{mol} \mathrm{s}{ }^{-1}$. During the measurement period, tubes containing desiccant and soda were used to control $\mathrm{H}_{2} \mathrm{O}$ and $\mathrm{CO}_{2}$, respectively inside the instrument chamber.

\subsubsection{Determination of cotton seedling biomass}

Three plants were randomly selected for each treatment, the shoots were separated from the roots, and the fresh weights were respectively weighed and put into sample bags. The samples were put into a sample bag at $105^{\circ} \mathrm{C}$ for 30 min and oven-dried at $75^{\circ} \mathrm{C}$ for $48 \mathrm{~h}$, the dry weight was then measured. 


\subsubsection{Determination of MDA and superoxide anion}

About $0.3 \mathrm{~g}$ of fresh leaf tissue was ground using a pestle and mortar. An amount of $3.0 \mathrm{~mL}$ of $0.05 \mathrm{M}$ precooled phosphate buffer (pH 7.8) was added to the homogenate, which was then centrifuged at $15000 \mathrm{~g}$ at $4^{\circ} \mathrm{C}$ for $20 \mathrm{~min}$. Lipid peroxidation was measured spectrophotometrically from MDA content using a thiobarbituric acid (TBA) reaction following the method described by Heath and Packer (1968). At the same time, the same supernatant Hydroxylamine was used to determine the superoxide anion production rate of leaves (Tian et al., 2003).

\subsubsection{Determination of protective enzyme activity}

About $0.3 \mathrm{~g}$ of fresh leaf tissue was ground using a pestle and mortar. An amount of $2.7 \mathrm{~mL}$ of $0.05 \mathrm{M}$ precooled phosphate buffer (pH 7.8) was added to the homogenate, which was then centrifuged at $15000 \mathrm{~g}$ at $4^{\circ} \mathrm{C}$ for $20 \mathrm{~min}$. After obtaining the supernatant, refer to the following method to determine the protective enzyme activity. SOD activity was determined spectrophotometrically from the inhibition of the photochemical reduction of nitroblue tetrazolium (NBT) at $560 \mathrm{~nm}$ (Dhindsa et al., 1981). POD activity was measured by the determination of guaiacol oxidation by $\mathrm{H}_{2} \mathrm{O}_{2}$ at $470 \mathrm{~nm}$ (Lacan and Baccou, 1998). CAT activity was measured by monitoring the disappearance of $\mathrm{H}_{2} \mathrm{O}_{2}$ at $240 \mathrm{~nm}$ (Jiang and Huang, 2001).

\subsubsection{Determination of ion content}

On the 10th day after the treatment, 3 cotton seedling leaves and roots were randomly selected for each treatment, oven-dried at $105^{\circ} \mathrm{C}$ for 30 $\mathrm{min}$, and then continued drying at $75^{\circ} \mathrm{C}$ for $48 \mathrm{~h}$. The dried leaves and roots were ground into powder. Each sample weighed at $0.1500 \mathrm{~g}$, digested with $\mathrm{H}_{2} \mathrm{SO}_{4}-\mathrm{H}_{2} \mathrm{O}_{2}$, and diluted in a $100 \mathrm{ml}$ volumetric flask. The filtered supernatant was used to determine the sodium $\left(\mathrm{Na}^{+}\right)$and potassium $\left(\mathrm{K}^{+}\right)$ion contents in the leaves and roots of cotton seedlings using a flame photometer. $\mathrm{Na}^{+}$uptake at the seedlings' root surface and $\mathrm{K}^{+}$translocation from root to shoot were computed by following the equations described by (Malik et al., 2010);Shabala and Mackay (2011), respectively.

\footnotetext{
Na ion uptake at root surface $=\frac{\text { Sum of Na concentration in cotton tissues }}{\text { Total root dry wright of cotton }}$

Translocation factor $=\frac{K \text { concentration in cotton leaves }}{K \text { concentrantion in cotton roots }}$
}

\subsection{Statistical analysis}

The test data is statistically analyzed using EXCEL 2020 and DPS V13.5 softwares. All experimental data were expressed as means \pm standard deviation. All treatment means $(n=3)$ were compared for any significant differences using Duncan's multiple range tests at $P<0.05$. Data fitting and graphical presentation were carried out in Origin-Pro 2021a (Origin Lab, Northampton, MA, USA). A general linear regression model was used to fit the relationships between parameters.

\section{Results}

\subsection{The effect of MT on cotton seedling biomass under low temperature and salt stress}

Compared with CK, the coupled stress of salt and low temperature reduced the dry weights of shoot and root of cotton seedlings (Figure 1ab), but the reduction of root dry weight did not reach a significant level. Under the salt stress condition at $25^{\circ} \mathrm{C}$, although the aboveground dry weight of cotton seedlings treated with exogenous MT increased slightly (compared with $0 \mu \mathrm{M}$ MT), it was not significant; and there was no significant difference between different MT treatments. Except for $200 \mu \mathrm{M}$ MT, exogenous MT significantly increased the root dry weight of cotton seedlings, and the highest value of cotton root dry weight was obtained in the $150 \mu \mathrm{M}$ MT treatment. Under the coupled stress of low temperature and salinity, exogenously applied MT insignificantly increased the aboveground and root dry weights of cotton seedlings; the maximum aboveground dry weight was obtained in the $100 \mathrm{mM}$ MT treatment.

\subsection{Effects of MT on gas exchange parameters of cotton seedling leaves under low temperature and salt stress}


Compared with CK, the coupled stress of low temperature and salinity significantly reduced $P_{n}, g_{s}, T_{n}$ and $C_{i}$ of cotton seedlings (Figure 2). Under the salt stress condition at $25^{\circ} \mathrm{C}$, with the increase of exogenous MT concentration, $P_{n}, g_{s}, T_{n}$ and $C_{i}$ all showed a trend of increase

firstly and then decreased in the $200 \mu \mathrm{M} \mathrm{MT}$ treatment compared with the non-MT treated saline treatment. Except for $C_{i}$ the highest values of gas exchange parameters appeared in the $150 \mu \mathrm{M} \mathrm{MT}$ treatment. Under the coupled stress of low temperature and salinity, the application of different concentrations of exogenous MT increased $P_{n}, g_{s}$ and $T_{r}$ of cotton seedlings, and with the increase of MT concentration, $P_{n}, g_{s}$, and $T_{r}$ also showed a trend of increasing and then decreasing, but the difference between MT concentrations is not significant. The highest value of $P_{n}$ was obtained with the $100 \mu \mathrm{M}$ MT treatment.

\subsection{The effect of MT on cotton seedling membrane damage under low temperature and salt stress}

Compared with $\mathrm{CK}(0 \mathrm{mM} \mathrm{NaCl})$, low temperature + salt stress insignificantly increased the superoxide anion production rate and MDA content in cotton seedling leaves (Figure 3 ). At $25^{\circ} \mathrm{C}$, the exogenously applied MT reduced the superoxide anion production rate and MDA content in cotton seedling leaves under salt stress. Compared with the MT-untreated saline treatment, the superoxide anion production rate was reduced by $29.6 \%$ under the $100 \mu \mathrm{M}$ MT treatment, and the MDA content was significantly reduced by $43.3-53.8 \%$ under the $100-200 \mu \mathrm{M}$ MT treatments, respectively. Under the coupled stress of low temperature and salt conditions, spraying different concentrations of MT, compared with MT-untreated saline treatment, the superoxide anion production rate dropped to the lowest value $0.0034 \mu \mathrm{mol} \mathrm{min}^{-1} \mathrm{mg}^{-1} \mathrm{prot}$ under the $150 \mu \mathrm{M}$ MT treatment. With the increase of exogenous MT concentration, the content of MDA in cotton seedling leaves gradually decreased under the coupled stress of low temperature and salt, and it significantly decreased to became stable when treated with 100 $200 \mu \mathrm{M}$ MT.

\subsection{The effect of MT on the antioxidant enzymes of cotton seedlings under low temperature and salt stress}

Table 1 shows the effect of exogenously applied MT on the antioxidant enzymes of cotton seedlings under low temperature and salt stress. Compared with $\mathrm{CK}(0 \mathrm{mM} \mathrm{NaCl})$, salt stress significantly reduced the SOD and POD contents in cotton seedling leaves (38\% and $31 \%)$, while increased the CAT content (100\%). The coupled stress of low temperature and salt significantly reduced the POD and CAT contents (67\% and $96 \%)$, slightly increased the SOD content. Compared with the MT-untreated saline treatment at $25^{\circ} \mathrm{C}$, exogenously sprayed MT significantly reduced the SOD and POD contents and insignificantly affected the CAT concentration in seedlings leaves. Compared with the MT-untreated saline treatment under the coupled stress of low temperature and salt, spraying 50-100 $\mu \mathrm{M}$ MT on the leaves of seedlings increased the SOD and POD contents, and decreased the CAT content. Compared with $0 \mu \mathrm{M}$ MT salt treatment under the dual stress of low temperature and salt, spraying 50-100 $\mathrm{MM}$ MT on the leaves increased the SOD and POD contents, and decreased the CAT content.

Through an interactive analysis between the treatments, it was found that different temperatures conditions had a significant effect on the SOD and CAT contents, but had an insignificant effect on POD of cotton seedling leaves under salt stress. Different MT concentrations had a significant impact on POD and CAT, while has an insignificant effect on SOD of cotton seedlings under salt stress. The content of POD and CAT in the leaves of cotton seedlings was affected by the interaction of temperature and MT.

\subsection{The effect of MT on ion homeostasis and absorption under different temperature and salt stress}

Figure 4 shows the effect of low temperature + salt stress on the ion homeostasis of cotton seedlings. The results showed that compared with the control, salt stress reduced the $\mathrm{K}^{+}$content in the seedlings leaves and roots by $15 \%$ and $50 \%$, and increased the $\mathrm{Na}^{+}$content by $422 \%$ and $249 \%$, respectively. The coupled stress of low temperature and salt slightly increased the $\mathrm{K}^{+}$content in the leaves, significantly reduced the $\mathrm{K}^{+}$content in the roots, and significantly increased the accumulation of $\mathrm{Na}^{+}$in the leaves and roots. After foliar spraying of different concentrations of $\mathrm{MT}$, the $\mathrm{K}^{+}$content in the roots under salt stress conditions was significantly increased, and the $\mathrm{K}^{+}$content in the leaves of cotton seedlings increased slightly. The $\mathrm{Na}^{+}$content in the leaves and roots of cotton seedlings was significantly reduced, but the difference between different concentrations of MT was insignificant. Compared with the MT-untreated saline treatment, the application of $50 \mu \mathrm{M}$ MT under salt stress, slightly increased the $\mathrm{K}^{+}$content in the leaves and roots of cotton seedlings, and different concentrations of $\mathrm{MT}$ significantly reduced the content of cotton seedlings. The content of $\mathrm{Na}^{+}$, although the amount of $\mathrm{Na}^{+}$in the root decreased, the difference was insignificant.

Compared with the control treatment, the coupled stress of low temperature and salt, significantly increased the $\mathrm{Na}^{+} / \mathrm{K}^{+}$ratio in the leaves and roots of cotton seedlings (542\% and $289 \%$, respectively) (Figure 5a,b), and significantly increased the $\mathrm{Na}^{+}$content on the surface of 
cotton seedling roots (585\%) (Figure 5d). Exogenous foliar spraying of different MT concentrations significantly reduced the $\mathrm{Na}^{+} / \mathrm{K}^{+}$ratio in the leaves and roots of cotton seedlings under salt stress at $25^{\circ} \mathrm{C}$, and correspondingly reduced the $\mathrm{Na}^{+}$absorption on the surface of cotton seedling roots. Under the coupled stress of low temperature and salt, with the increase of MT concentration, the $\mathrm{Na}^{+} / \mathrm{K}^{+}$ratio in the leaves of cotton seedlings firstly decreased and then increased. The $\mathrm{Na}^{+} / \mathrm{K}^{+}$ratio in the roots increased and then decreased, correspondingly reducing the root surface absorption of $\mathrm{Na}^{+}$. On the other hand, compared with the control, the coupled stress of low temperature and salt significantly increased the transfer of $\mathrm{K}^{+}$ion from roots to shoot and then from shoot to leaves of cotton seedlings. After exogenously foliar spraying of different concentrations of $\mathrm{MT}$, the low temperature + salt stress significantly increased $\mathrm{K}^{+}$transport from roots to aboveground parts. Compared with the MT-untreated saline treatment, different concentrations of MT slightly reduced the transport of $\mathrm{K}^{+}$from roots to shoot.

\section{Discussion}

Abiotic stresses such as salinity and low temperature severely limit the growth and development of plants. Moreover, nearly $50 \%$ of the annual yield loss of major crops worldwide is related to abiotic stresses (Valliyodan and Nguyen, 2006). The coupled effect of low temperature and salt stress reduces plants' leaf area, relative water content, water potential, transpiration rate, fresh weight and dry weight of plant stems and roots (Wang et al., 2017). To gain new knowledge of cotton seedlings responses to exogenously applied melatonin under combined low temperature and salt stress, seedlings in a phytotron were foliar sprayed with MT to identify their physiological and biochemical responses. In this study, the combined effect of low temperature and salt stress has significantly and negatively affected seedlings' physiological and biochemical mechanisms. In agreement with our findings, previous studies have concluded that the effects of coupled stress on crop growth and productivity may be devastating (Mittler, 2006;Mittler and Blumwald, 2010). For example, drought and high temperature, salinity and high temperature, ozone and salinity, ozone and high temperature, nutrient stress and drought, nutrient stress and salinity, ultraviolet light and high temperature, ultraviolet light and drought, strong light and heat, drought or low temperature and other stress interactions showed significant negatives impacts on crop yield (Mittler and Blumwald, 2010;Suzuki et al., 2014). Literatures reported that combined stress such as drought + high temperature stress has a more serious negative impact on the number of wheat tillers, chlorophyll content, yield and harvest index than a single stress of drought or high temperature (Zandalinas et al., 2016a;Zandalinas et al., 2016b). In this study, the combination of low temperature + salinity stress has a greater impact on cotton seedling biomass than the single salt stress or single Low temperature stress. This is mainly related to the senescence and dehydration of plant cells under abiotic stress, and salinity limits cell elongation and division, which leads to a decrease in the growth rate of roots and aboveground parts, and a decrease in dry matter accumulation (Khalil et al., 2022).

Photosynthesis is the basic source of the existence, prosperity and development of life on earth. Photosynthesis is the basis of plant growth and development, but it is susceptible to environmental stresses (particularly sensitive to low temperature stress). The main components of photosynthesis (electron transport, Calvin cycle, stomatal conductance) were destroyed under low temperature stress (Hu et al., 2016). In this study, $g_{s}$ and $T_{r}$ decreased in response to salinity alone, low temperature alone and salinity + low temperature and plants reduced water loss by closing their stomata. The closing of stomata leads to insufficient $\mathrm{CO}_{2}$ and inhibits photosynthesis. This is consistent with the research results of Chatrath et al. (2000), who reported that plant may close their stomata under saline conditions in order to reduce water loss. After exogenous foliar supplementation with MT, the aboveground and underground biomass under the different stresses of salinity, low temperature, and salinity + low temperature was increased. This is related to the ability of MT to regulate the physical process of cell wall extension to induce plant root growth and promote the accumulation of dry matter (Sarropoulou et al., 2012). After the foliar application of MT, the $g_{s}$ and $T_{r}$ of cotton seedlings were increased, thereby increasing their $P_{n}$. This is consistent with the research results of Irshad et al. (2021) and Zhang et al. (2021), who observed that exogenous MT has significantly improved $P_{n}$ under low temperature stress and salt stress, respectively.

The normal transportation of substances and ions in plants mainly depends on the integrity of the structure and function of the biofilm. When the plant is subjected to abiotic stress, plant's biofilm system is the first to be impacted and damaged. One of the damages caused by abiotic stress to cell membranes is lipid peroxidation. The final product of peroxidation damage to cell membranes by reactive oxygen species is MDA. The production of reactive oxygen species (ROS) such as $\mathrm{H}_{2} \mathrm{O}_{2}$, superoxide anion, hydroxyl anion, and MDA under salt conditions severely destroys chlorophyll content, destroys lipids and mitochondria, and causes plant necrosis (Mohsin et al., 2020). In this study, under the different stresses of $150 \mathrm{mM} \mathrm{NaCl}, 15^{\circ} \mathrm{C}$ low temperature and $150 \mathrm{mM} \mathrm{NaCl}+$ low temperature, cotton seedlings MDA content increased compared with the control, and at the same time the superoxide anion production rate increased, which led to membrane lipid peroxidation. The research results are consistent with those of Parveen et al. (2021). Abiotic stress causes an increase in the level of active oxygen in the plant body and simultaneously activates the defense system to reduce the harm of active oxygen. SOD, CAT and POD are the key enzymes to remove active oxygen in cells, and the ability to remove active oxygen depends on the coordination of these enzymes 
(Hernandez et al., 2000). As the first line of defense for ROS removal, SOD can disproportionate superoxide anions into $\mathrm{O}_{2}$ and $\mathrm{H}_{2} \mathrm{O}_{2}$, and POD and CAT can remove $\mathrm{H}_{2} \mathrm{O}_{2}$ in peroxisomes (Anjum et al., 2017). In this experiment, compared with the control, the coupled stress of salt and low temperature and salt stress increased the content of CAT and decreased the content of SOD and POD, while the low temperature stress increased the content of POD and CAT, and decreased the content of SOD. MT can increase the activity of protective enzymes to alleviate the damage caused by abiotic stress to plants. Studies have shown that the application of exogenous MT can increase the content of SOD, POD and CAT in cucumber under salt stress environment (Wang et al., 2016), increase the content of SOD in wheat (Turk et al., 2014) and cucumber (Marta et al., 2016) under low temperature stress. In addition, under salt and heat stress, applying MT increased tomato CAT content and reduced SOD content (Martinez et al., 2018). In this experiment, after applying the exogenous MT, compared with the salt treatment without the exogenous MT, the exogenous spraying of MT at a concentration of $50 \mu \mathrm{M}$ increased the POD and CAT content of cotton seedlings, while at low temperature + Under salt double stress, spraying 50-150 $\mu \mathrm{M}$ MT significantly increased the SOD and POD content of cotton seedlings. Through interactive analysis, it is known that temperature has a very significant impact on SOD and CAT, and MT has a very significant impact on POD and CAT. At the same time, POD and CAT are affected by the interaction of temperature and MT.

Under salt stress, the excessive accumulation of $\mathrm{Na}^{+}$in plant cells leads to the production of ROS, which breaks the dynamic balance of the scavenging system, and initiates membrane lipid peroxidation and degreasing. The membrane structure is destroyed and the MDA content increases (Hernandez et al., 2000). In this study, after exogenous foliar supplementation with MT under salt stress, the opposite conclusion was reached and found that the $\mathrm{Na}^{+}$content in cotton seedlings was reduced, the protective enzyme activity was increased, the degree of membrane damage was reduced, and the photosynthetic parameters and dry matter content were increased. The reason is that exogenous MT regulates the physiological mechanism of cotton seedlings to resist adversity under salt stress. As shown in Figure $5 \mathrm{a}$, except that the protective enzyme activity of cotton seedlings unilaterally affects photosynthetic parameters. Biomass is not directly affected by photosynthetic parameters and membrane damage and other parameters have no mutual influence. Previous study reported that the high accumulation of $\mathrm{Na}^{+}$in the apoplasts of roots and stems easily triggers osmotic stress (Zhao et al., 2020). The higher accumulation of Na leads to an increase in the ratio of $\mathrm{Na}^{+} / \mathrm{K}^{+}$ratio and promotes ion imbalance, thereby hindering metabolic functions and destroying plant activities (Mohsin et al., 2020). For example, photosynthesis declines and dry matter accumulation decreases, which ultimately leads to reduced crop growth (Sarropoulou et al., 2012), production of reactive oxygen species (Shahzad et al., 2017), and plant damage. The results of this study showed that, compared with the control, the different stresses of salinity and low temperature + salinity reduced the $\mathrm{K}^{+}$ accumulation in the leaves and roots of cotton seedlings, and significantly increased the accumulation of $\mathrm{Na}^{+}$, resulting in a significant increase in the ratio of $\mathrm{Na}^{+} / \mathrm{K}^{+}$, and at the same time increased the absorption of $\mathrm{Na}^{+}$. However, after spraying the exogenous $\mathrm{MT}$, the Na accumulation in the leaves and roots of seedlings was significantly reduced. The $\mathrm{K}^{+}$accumulation in the leaves of the seedlings was increased, and the $\mathrm{Na}^{+} / \mathrm{K}^{+}$ratio of seedlings was reduced. Since the $\mathrm{K}^{+}$dynamic balance is affected by the accumulation of $\mathrm{Na}^{+}$, an appropriate $\mathrm{Na}^{+} / \mathrm{K}^{+}$should be maintained to improve the salt tolerance of crops (Rasouli et al., 2021). Studies have found that under abiotic stress, plants closing stomata and reducing transpiration may limit the transport of $\mathrm{Na}^{+}$to plant tissues (Perin et al., 2019). In the current study, through interactive analysis, temperature significantly affects $\mathrm{K}^{+}, \mathrm{Na}^{+}, \mathrm{Na}^{+} / \mathrm{K}^{+}$ratio, $\mathrm{Na}^{+}$absorption and $\mathrm{K}^{+}$transport in roots and leaves, except for the insignificant effect of temperature on the $\mathrm{Na}^{+}$content in leaves. The influence of exogenous $\mathrm{MT}$ on $\mathrm{K}^{+}$content is insignificant. The $\mathrm{Na}^{+}$content in root removal is not affected by the interaction of temperature and MT, and the others are all affected by the interaction of temperature and MT.

Studies have shown that low temperature stress can enhance the antioxidant defense ability by regulating the metabolic and photosynthetic reactions of tea plants, wheat, Arabidopsis and other plants, thereby improving the cold tolerance of plants (Yu et al., 2018;Li et al., 2019). The results of this study are that when exogenous MT is applied under low temperature + salt stress, the ion content directly affects the protective enzymes, photosynthetic parameters, membrane damage and biomass, while the protective enzymes and photosynthetic parameters negatively affect the ion content. Protective enzymes affect membrane damage in one direction, and have a two-way effect on photosynthesis (Figure 6). In summary, through interactive analysis, temperature has a significant effect on the aboveground and underground biomasses under salt stress conditions. Exogenous MT successfully increased the biomass and physiological and biochemical indexes of cotton seedlings under the stresses of salt and low temperature + salt. In addition, reducing the absorption of ROS and $\mathrm{Na}^{+}{ }^{+}$ plants is the focus of this study, indicating that exogenous MT has the potential to store crop growth under salt stress. The relationships between various parameters of cotton seedlings at $15^{\circ} \mathrm{C}$ and $25^{\circ} \mathrm{C}$ under salt stress condition were shown in Figure 7 and Table 3 . It was observed that improving antioxidant enzymes activities with exogenous MT turns to an improvement of leaf gas exchange parameters and $\mathrm{K}^{+}$uptake, while decreased $\mathrm{Na}^{+}$uptake. 
Table 3

Stepwise regression of parameters of salt-stressed cotton seedlings at $15^{\circ} \mathrm{C}$ and $25^{\circ} \mathrm{C}$ under exogenous melatonin.

\begin{tabular}{|c|c|c|c|c|c|c|c|}
\hline \multirow{2}{*}{\multicolumn{2}{|c|}{$\begin{array}{l}\text { Independent } \\
\text { variable }\end{array}$}} & \multicolumn{3}{|c|}{ Low temperature $\left(15^{\circ} \mathrm{C}\right)+$ salt stress $(150 \mathrm{mM})$} & \multicolumn{3}{|l|}{$25^{\circ} \mathrm{C}+$ salt stress $(150 \mathrm{mM})$} \\
\hline & & \multirow{2}{*}{$\begin{array}{l}\text { Stepwise regression equation } \\
y=1.443 \times 2+0.266\end{array}$} & & \multirow{2}{*}{$\begin{array}{l}P \\
0.01\end{array}$} & \multirow{2}{*}{$\begin{array}{l}\text { Stepwise regression equation } \\
y=0.20 \times 12+0.192 \times 14-0.101 \times 16+0.147\end{array}$} & \multirow{2}{*}{$\begin{array}{l}\mathbf{R}^{2} \\
0.87\end{array}$} & \multirow{2}{*}{$\begin{array}{l}P \\
0.00\end{array}$} \\
\hline $\mathrm{X} 1$ & $\begin{array}{l}\text { shoot dry } \\
\text { weight }\end{array}$ & & & & & & \\
\hline $\mathrm{x} 2$ & $\begin{array}{l}\text { root dry } \\
\text { weight }\end{array}$ & $y=0.278 \times 1+0.023$ & 0.40 & 0.01 & $y=-0.070 \times 17+0.244$ & 0.47 & 0.00 \\
\hline X3 & $\mathrm{Pn}$ & $y=-0.014 \times 5+3.090 \times 6+0.398 \times 10+2.046$ & 0.97 & 0.00 & $y=3.558 \times 6+2.126$ & 0.72 & 0.00 \\
\hline $\mathrm{X} 4$ & gs & $y=-0.002 \times 12+0.001 \times 10+0.061 \times 6+0.034$ & 1.00 & 0.00 & $y=0.002 \times 13+0.001 \times 9+0.000 \times 5-0.108$ & 0.92 & 0.00 \\
\hline$x 5$ & $\mathrm{Ci}$ & $y=-135.623 \times 17-269.164$ & 0.39 & 0.06 & $y=891.435 x 4+122.900$ & 0.72 & 0.00 \\
\hline $\mathrm{x} 6$ & $\operatorname{Tr}$ & $y=0.025 \times 12-0.016 \times 10+15.698 \times 4-0.468$ & 0.99 & 0.00 & $y=0.203 \times 3-0.033$ & 0.72 & 0.00 \\
\hline $\mathrm{X} 7$ & MDA & $y=-0.002 \times 9+0.635$ & 0.23 & 0.04 & $y=-0.070 \times 10+0.007 \times 9+0.209 \times 17+0.120$ & 0.92 & 0.00 \\
\hline $\mathrm{x} 8$ & $\begin{array}{l}\text { Superoxide } \\
\text { anion }\end{array}$ & $y=0.000 \times 14-0.005$ & 0.26 & 0.03 & I & / & / \\
\hline X9 & SOD & $y=205.005 \times 17-49.711$ & 0.40 & 0.01 & $\begin{array}{l}y=-1.211 \times 15+7.685 \times 10+101.543 \times 7- \\
1.916\end{array}$ & 0.96 & 0.00 \\
\hline $\mathrm{X} 10$ & POD & $\begin{array}{l}y=0.125 \times 15+130.185 \times 4+2.404 \times 11- \\
0.422\end{array}$ & 0.98 & 0.00 & $y=-4.530 \times 7+32.189 \times 11+0.083 \times 9+0.531$ & 0.85 & 0.00 \\
\hline $\mathrm{X} 11$ & CAT & $y=-0.052 \times 15-2.979 \times 6+0.329 \times 10-0.498$ & 0.96 & 0.00 & $y=0.002 \times 14-0.114 \times 7+0.073$ & 0.73 & 0.00 \\
\hline $\mathrm{X} 12$ & $\mathrm{~K}^{+}-\mathrm{L}$ & $\begin{array}{l}y=-0.057 \times 16+0.042 \times 15- \\
35.334 \times 4+0.604 \times 13+22.223 \times 17- \\
11.876\end{array}$ & 0.96 & 0.00 & $y=37.733 x 4+16.815$ & 0.57 & 0.00 \\
\hline $\mathrm{X} 13$ & $\mathrm{~K}^{+}-\mathrm{R}$ & $\begin{array}{l}y=0.42 \times 11+48.308 \times 4+1.020 \times 12- \\
33.413 \times 17+31.137\end{array}$ & 1.00 & 0.00 & $\begin{array}{l}y=0.237 \times 16+1.078 \times 12- \\
23.081 \times 17+20.755\end{array}$ & 0.99 & 0.00 \\
\hline $\mathrm{X} 14$ & $\mathrm{Na}^{+}-\mathrm{L}$ & $y=4.983 \times 2+9.996 \times 1+0.492 \times 16-5.787$ & 0.99 & 0.00 & $y=-0.896 \times 7+4.021 \times 1+0.534 \times 16-1.744$ & 1.00 & 0.00 \\
\hline $\mathrm{X} 15$ & $\mathrm{Na}^{+}-\mathrm{R}$ & $\begin{array}{l}y=0.758 \times 13- \\
4.227 \times 11+4.298 \times 12+2.025 \times 14- \\
110.436\end{array}$ & 0.87 & 0.00 & $y=17.741 \times 17-0.150 \times 9+6.932$ & 0.91 & 0.00 \\
\hline $\mathrm{X} 16$ & $\mathrm{Na}^{+}$-uptake & $\begin{array}{l}y=-0.993 \times 2- \\
20.381 \times 1+2.027 \times 14+11.795\end{array}$ & 1.00 & 0.00 & $y=1.713 \times 7-7.595 \times 1+1.869 \times 14+3.308$ & 1.00 & 0.00 \\
\hline $\mathrm{X} 17$ & $\begin{array}{l}\mathrm{K}^{+} \\
\text {translocation }\end{array}$ & $\begin{array}{l}y=0.011 \times 11+1.427 \times 4+0.031 \times 12- \\
0.030 \times 13+0.912\end{array}$ & 1.00 & 0.00 & $\begin{array}{l}y=0.119 \times 7+0.012 \times 16+0.040 \times 12- \\
0.039 \times 13+0.856\end{array}$ & 0.99 & 0.00 \\
\hline $\begin{array}{l}\text { Not } \\
\text { con } \\
\mathrm{K}^{+} \mathrm{t}\end{array}$ & $\begin{array}{l}\text { SDW, shoot dry } \\
\text { itration; } T r \text {, tran } \\
\text { slocation. }\end{array}$ & $\begin{array}{l}\text { ight; } \mathrm{RDW} \text {, root dry weight, } P n \text {, net pho } \\
\text { iration rate; } \mathrm{K}-\mathrm{L} \text {, leaf } \mathrm{K}^{+} \text {content; } \mathrm{K}-\mathrm{R} \text {, rc }\end{array}$ & वा & ate; & $\begin{array}{l}\text { stomatal conductance; } \mathrm{C} \text {, intracellular } \\
\text { leaf } \mathrm{Na}^{+} \text {content; } \mathrm{Na}-\mathrm{R} \text {, root } \mathrm{Na}^{+} \text {conten }\end{array}$ & 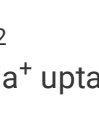 & \\
\hline
\end{tabular}

In summary, exogenous melatonin has different regulatory mechanisms on the ion content, photosynthetic parameters, membrane damage, protective enzymes activities and biomass accumulation of cotton seedlings under coupled salt and low temperature stress (Figure 6). Protecting enzymes under salt stress affects photosynthesis in one direction, while under low temperature and salt stress the two interact with each other. The protection enzyme activity under salt stress affects membrane damage one-way, ion content one-way affects membrane damage and biomass, while under low temperature and salt dual stress, the protection enzyme and membrane damage, ion content and membrane damage and biomass are two-way effects. Under double coercion, MT's adjustment of the above parameters is more complex.

\section{Conclusion}

The results showed that under salt stress and coupled low temperature and salt stress, the spraying of 50 to $150 \mathrm{MT}$ on the leaf surface increased the biomass, $P_{n}$, and SOD and POD activities, while reduced membrane damage of cotton seedling leaves. As a result, the absorption of $\mathrm{K}^{+}$reduces the accumulation of $\mathrm{Na}^{+}$. The regulatory mechanism of external supplementary MT on salt stress and salt stress 
and low temperature stress is different. The regulation of the mechanism under low temperature and salt stress is more complex. In this study, the lack of MT alleviates the abiotic stress mechanism of cotton seedlings in a more in-depth study, the next step can focus on the study of the metabolic pathway changes of cotton seedlings under abiotic stress by the exogenous substance MT.

\section{Declarations}

\section{Author contributions}

Conceptualization, X.W. and Y.G.; methodology, A.K.M.H.; software, A.S.A.; validation, X.W., and Y.G.; formal analysis, Y.F., and W.S.; investigation, W.S., and H.W.; data curation, Y.F.; writing-original draft preparation, A.K.M.H., and Y.F.; writing-review and editing, A.K.M.H., A.Q. and Y.G.; funding acquisition, X.W., and Y.G. All authors have read and agreed to the published version of the manuscript.

\section{Declaration of Competing Interest}

The authors declare that they have no known competing financial interests or personal relationships that could have appeared to influence the work reported in this paper.

\section{Founding}

This work was supported by the National Natural Science Foundation of China (No. 51879267, 51790534), China Agriculture Research System of MOF and MARA (CARS-15-13), XPCC finance science and technology project (2021AA003), and the Agricultural Science and Technology Innovation Program (ASTIP), Chinese Academy of Agricultural Sciences.

\section{References}

1. Airaki M, Leterrier M, Mateos RM, Valderrama R, Chaki M, Barroso JB, Del Rio LA, Palma JM, Corpas FJ (2012). Metabolism of reactive oxygen species and reactive nitrogen species in pepper (Capsicum annuum L.) plants under low temperature stress. Plant Cell Environ $35,281-295$.

2. Anjum SA, Ashraf U, Tanveer M, Khan I, Hussain S, Shahzad B, Zohaib A, Abbas F, Saleem MF, Ali I (2017). Drought induced changes in growth, osmolyte accumulation and antioxidant metabolism of three maize hybrids. Front Plant Sci, 8.

3. Arnao MB, and Hernández-Ruiz J (2006). The physiological function of melatonin in plants. Plant Signal Behav 1,89-95.

4. Ashraf M, Foolad MR (2007). Roles of glycine betaine and proline in improving plant abiotic stress resistance. Environ Exp Bot 59, 206216.

5. Bajwa VS, Shukla MR, Sherif SM, Murch SJ, Saxena PK (2014). Role of melatonin in alleviating cold stress in A rabidopsis thaliana. J Pineal Res 56, 238-245.

6. Byeon Y, Back K (2014). An increase in melatonin in transgenic rice causes pleiotropic phenotypes, including enhanced seedling growth, delayed flowering, and low grain yield. J Pineal Res 56, 408-414.

7. Calvo JR, Gonzalez-Yanes C, Maldonado M (2013). The role of melatonin in the cells of the innate immunity: a review. J Pineal Res 55, 103-120.

8. Chatrath A, Mandal P, Anuradha M (2000). Effect of secondary salinization on photosynthesis in fodder oat (Avena sativa L.) genotypes. J Agron Crop Sci 184, 13-16.

9. Çiçek N, Çakırlar H (2008). Effects of salt stress on some physiological and photosynthetic parameters at three different temperatures in six soya bean (Glycine max L. Merr.) cultivars. J Agron Crop Sci 194, 34-46.

10. Demiral, T, Türkan I (2006). Exogenous glycinebetaine affects growth and proline accumulation and retards senescence in two rice cultivars under $\mathrm{NaCl}$ stress. Environ Exp Bot 56, 72-79.

11. Dhindsa RS, Plumb-Dhindsa P, Thorpe TA (1981). Leaf senescence: correlated with increased levels of membrane permeability and lipid peroxidation, and decreased levels of superoxide dismutase and catalase. J Exp Bot 32, 93-101.

12. Ding F, Liu B, Zhang S (2017). Exogenous melatonin ameliorates cold-induced damage in tomato plants. Sci Hortic 219, $264-271$.

13. Dong Y, Jinc S, Liu S, Xu L, Kong J (2014). Effects of exogenous nitric oxide on growth of cotton seedlings under NaCl stress. J Soil Sci Plant Nutr 14, 1-13.

14. Fan J, Hu Z, Xie Y, Chan Z, Chen K, Amombo E, Chen L, Fu J (2015). Alleviation of cold damage to photosystem II and metabolisms by melatonin in Bermudagrass. Front Plant Sci 6, 925. 
15. Hamani AKM, Chen J, Soothar MK, Wang G, Shen X, Gao Y, Qiu R (2021). Application of Exogenous Protectants Mitigates Salt-Induced $\mathrm{Na}(+)$ Toxicity and Sustains Cotton (Gossypium hirsutum L.) Seedling Growth: Comparison of Glycine Betaine and Salicylic Acid. Plants (Basel) 10.

16. Hamani AKM, Wang G, Soothar MK, Shen X, Gao Y, Qiu R, Mehmood F (2020). Responses of leaf gas exchange attributes, photosynthetic pigments and antioxidant enzymes in $\mathrm{NaCl}$-stressed cotton (Gossypium hirsutum L.) seedlings to exogenous glycine betaine and salicylic acid. BMC Plant Biol 20, 1-14.

17. Hardeland R (2016). Melatonin in plants-diversity of levels and multiplicity of functions. Front Plant Sci 7, 198.

18. Hattori A, Migitaka H, ligo M, Itoh M, Yamamoto K, Ohtani-Kaneko R, Hara M, Suzuki T, Reiter RJ (1995). Identification of melatonin in plants and its effects on plasma melatonin levels and binding to melatonin receptors in vertebrates. Biochem Mol Biol Int 35, 627-634.

19. Heath RL, Packer L (1968). Photoperoxidation in isolated chloroplasts: I. Kinetics and stoichiometry of fatty acid peroxidation. Arch Biochem Biophys 125, 189-198.

20. Hernandez JA, Jiménez A, Mullineaux P, Sevilia F (2000). Tolerance of pea (Pisum sativum L.) to long-term salt stress is associated with induction of antioxidant defences. Plant Cell Environ 23, 853-862.

21. Hu Z, Fan J, Xie Y, Amombo E, Liu A, Gitau MM, Khaldun A, Chen L, Fu J (2016). Comparative photosynthetic and metabolic analyses reveal mechanism of improved cold stress tolerance in bermudagrass by exogenous melatonin. Plant Physiol Bioch 100, 94-104.

22. Irshad A, Rehman RNU, Kareem HA, Yang P, Hu T (2021). Addressing the challenge of cold stress resilience with the synergistic effect of Rhizobium inoculation and exogenous melatonin application in Medicago truncatula. Ecotox Environ Safe 226, 112816.

23. Jiang Y, Huang B (2001). Effects of calcium on antioxidant activities and water relations associated with heat tolerance in two coolseason grasses. J Exp Bot 52, 341-349.

24. Khalil R, Yusuf M, Bassuony F, Haroun S, Gamal A (2022). Alpha-tocopherol reinforce selenium efficiency to ameliorates salt stress in maize plants through carbon metabolism, enhanced photosynthetic pigments and ion uptake. S Afr J Bot 144, 1-9.

25. Lacan D, Baccou JC (1998). High levels of antioxidant enzymes correlate with delayed senescence in nonnetted muskmelon fruits. Planta 204, 377-382.

26. Li J, Arkorful E, Cheng S, Zhou Q, Li H, Chen X, Sun K, Li X (2018). Alleviation of cold damage by exogenous application of melatonin in vegetatively propagated tea plant (Camellia sinensis (L.) O. Kuntze). Sci Hortic 238, 356-362.

27. Li J, Yang Y, Sun K, Chen Y, Chen X, Li X (2019). Exogenous melatonin enhances cold, salt and drought stress tolerance by improving antioxidant defense in tea plant (Camellia sinensis (L.) O. Kuntze). Molecules 24, 1826.

28. Liang C, Zheng G, Li W, Wang Y, Hu B, Wang H, Wu H, Qian Y, Zhu XG, Tan DX (2015). Melatonin delays leaf senescence and enhances salt stress tolerance in rice. $J$ Pineal Res 59, 91-101.

29. Lichtenthaler H, Langsdorf G, Lenk S, Buschmann C (2005). Chlorophyll fluorescence imaging of photosynthetic activity with the flashlamp fluorescence imaging system. Photosynthetica 43, 355-369.

30. Malik RN, Husain SZ, Nazir I (2010). Heavy metal contamination and accumulation in soil and wild plant species from industrial area of Islamabad, Pakistan. Pak J Bot 42, 291-301.

31. Marta B, Szafrańska K, Posmyk MM (2016). Exogenous melatonin improves antioxidant defense in cucumber seeds (Cucumis sativus L.) germinated under chilling stress. Front Plant Sci 7, 575.

32. Martinez V, Nieves-Cordones M, Lopez-Delacalle M, Rodenas R, Mestre TC, Garcia-Sanchez F, Rubio F, Nortes PA, Mittler R, Rivero RM (2018). Tolerance to stress combination in tomato plants: New insights in the protective role of melatonin. Molecules $23,535$.

33. Mishra S, Kumar S, Saha B, Awasthi J, Dey M, Panda SK, Sahoo L (2016). "Crosstalk between Salt, Drought, and Cold Stress in Plants: Toward Genetic Engineering for Stress Tolerance," in Abiotic Stress Response in Plants.), 57-88.

34. Mittler R (2006). Abiotic stress, the field environment and stress combination. Trends Plant Sci 11, 15-19.

35. Mittler R, Blumwald E (2010). Genetic engineering for modern agriculture: challenges and perspectives. Annu Rev Plant Bio/61, 443-462.

36. Mohsin SM, Hasanuzzaman M, Parvin K, Fujita M (2020). Pretreatment of wheat (Triticum aestivum L.) seedlings with 2, 4-D improves tolerance to salinity-induced oxidative stress and methylglyoxal toxicity by modulating ion homeostasis, antioxidant defenses, and glyoxalase systems. Plant Physiol Bioch 152, 221-231.

37. Mukherjee S, David A, Yadav S, Baluška F, Bhatla SC (2014). Salt stress-induced seedling growth inhibition coincides with differential distribution of serotonin and melatonin in sunflower seedling roots and cotyledons. Physiol Plantarum 152, 714-728.

38. Munns R (2002). Comparative physiology of salt and water stress. Plant Cell Environ 25, 239-250.

39. Naing AH, Kim CK (2021). Abiotic stress-induced anthocyanins in plants: Their role in tolerance to abiotic stresses. Physiol Plantarum 172, 1711-1723. 
40. Parida AK, Das AB (2005). Salt tolerance and salinity effects on plants: a review. Ecotox Environ Safe 60, $324-349$.

41. Parveen A, Ahmar S, Kamran M, Malik Z, Ali A, Riaz M, Abbasi GH, Khan M, Sohail AB, Rizwan M (2021). Abscisic acid signaling reduced transpiration flow, regulated $\mathrm{Na}+$ ion homeostasis and antioxidant enzyme activities to induce salinity tolerance in wheat (Triticum aestivum L.) seedlings. Environ Tech Innov 24, 101808.

42. Perin EC, Da Silva Messias R, Borowski JM, Crizel RL, Schott IB, Carvalho IR, Rombaldi CV, Galli V (2019). ABA-dependent salt and drought stress improve strawberry fruit quality. Food Chem 271, 516-526.

43. Rasouli F, Kiani-Pouya A, Tahir A, Shabala L, Chen Z, Shabala S (2021). A comparative analysis of stomatal traits and photosynthetic responses in closely related halophytic and glycophytic species under saline conditions. Environ Exp Bot 181, 104300.

44. Saeed NA, Ahmad M, Mukhtar Z (2021). "GM Cotton for Stress Environments," in Cotton Precision Breeding. Springer), 257-280.

45. Sarropoulou VN, Therios IN, Dimassi-Theriou KN (2012). Melatonin promotes adventitious root regeneration in in vitro shoot tip explants of the commercial sweet cherry rootstocks CAB-6P (Prunus cerasus L.), Gisela 6 (P. cerasus $\times$ P. canescens), and MxM 60 (P. avium× P. mahaleb). J Pineal Res 52, 38-46.

46. Shabala S, Mackay A (2011). Ion transport in halophytes. Advances in Botanical Research 57, 151-199.

47. Shahzad, R, Khan AL, Bilal S, Waqas M, Kang SM, Lee IJ (2017). Inoculation of abscisic acid-producing endophytic bacteria enhances salinity stress tolerance in Oryza sativa. Environ Exp Bot 136, 68-77.

48. Sharma A, Wang J, Xu D, Tao S, Chong S, Yan D, Li Z, Yuan H, Zheng B (2020). Melatonin regulates the functional components of photosynthesis, antioxidant system, gene expression, and metabolic pathways to induce drought resistance in grafted Carya cathayensis plants. Sci Total Environ 713, 136675.

49. Shen J, Chen D, Zhang X, Song L, Dong J, Xu Q, Hu M, Cheng Y, Shen F, Wang W (2021). Mitigation of salt stress response in upland cotton (Gossypium hirsutum) by exogenous melatonin. J Plant Res, 1-15.

50. Shi H, Jiang C, Ye T, Tan DX, Reiter RJ, Zhang H, Liu R, Chan Z (2015). Comparative physiological, metabolomic, and transcriptomic analyses reveal mechanisms of improved abiotic stress resistance in bermudagrass [Cynodon dactylon (L). Pers.] by exogenous melatonin. J Exp Bot 66, 681-694.

51. Sun B, Liu GL, Phan TT, Yang LT, Li YR, Xing YX (2017). Effects of cold stress on root growth and physiological metabolisms in seedlings of different sugarcane varieties. Sugar Tech 19, 165-175.

52. Suzuki N, Rivero RM, Shulaev V, Blumwald E, Mittler R (2014). Abiotic and biotic stress combinations. New Phytol $203,32-43$.

53. Tian M, Gu Q, Zhu M (2003). The involvement of hydrogen peroxide and antioxidant enzymes in the process of shoot organogenesis of strawberry callus. Plant Sci 165, 701-707.

54. Turk H, Erdal S, Genisel M, Atici O, Demir Y, Yanmis D (2014). The regulatory effect of melatonin on physiological, biochemical and molecular parameters in cold-stressed wheat seedlings. Plant Growth Regul 74, 139-152.

55. Valliyodan B, Nguyen HT (2006). Understanding regulatory networks and engineering for enhanced drought tolerance in plants. Curr Opin Plant Biol 9, 189-195.

56. Wang L, Liu J, Wang W, Sun Y (2016). Exogenous melatonin improves growth and photosynthetic capacity of cucumber under salinityinduced stress. Photosynthetica 54, 19-27.

57. Wang Y, Ma L, Zhou R, Tang X, Bai Y (2017). Effects of salt stress on photosynthetic characteristics and indexes of adverse circumstances-resistance of Isatis indigotica Fort. seedlings from five areas. J Nanjing Agr Univ 40, 416-424.

58. Xie F, Wang Q, Sun R, Zhang B (2015). Deep sequencing reveals important roles of microRNAs in response to drought and salinity stress in cotton. J Exp Bot 66, 789-804.

59. Yan P, Li G, Sun H, Zhang Z, Yang R, Sun J (2021). Can arbuscular mycorrhizal fungi and biochar enhance plant resistance to lowtemperature stress? Agron $J$ 113, 1457-1466.

60. Yu Y, Lv Y, Shi Y, Li T, Chen Y, Zhao D, Zhao Z (2018). The role of phyto-melatonin and related metabolites in response to stress. Molecules 23, 1887.

61. Zandalinas SI, Balfagón D, Arbona V, Gómez-Cadenas A, Inupakutika MA, Mittler R (2016a). ABA is required for the accumulation of APX1 and MBF1c during a combination of water deficit and heat stress. J Exp Bot 67, 5381-5390.

62. Zandalinas SI, Rivero RM, Martínez V, Gómez-Cadenas A, Arbona V (2016b). Tolerance of citrus plants to the combination of high temperatures and drought is associated to the increase in transpiration modulated by a reduction in abscisic acid levels. BMC Plant Biol $16,1-16$.

63. Zhan Y, Wu T, Zhao X, Wang Z, Chen Y (2021). Comparative physiological and full-length transcriptome analyses reveal the molecular mechanism of melatonin-mediated salt tolerance in okra (Abelmoschus esculentus L.). BMC Plant Biol 21, 1-16.

64. Zhang HM, Zhang Y (2014). Melatonin: a well-documented antioxidant with conditional pro-oxidant actions. J Pineal Res 57, $131-146$.

Page $12 / 17$ 
65. Zhang Y, Zhou X, Dong Y, Zhang F, He Q, Chen J, Zhu S, Zhao T (2021). Seed priming with melatonin improves salt tolerance in cotton through regulating photosynthesis, scavenging reactive oxygen species and coordinating with phytohormone signal pathways. Ind Crop Prod 169, 113671.

66. Zhao C, Nawaz G, Cao Q, Xu T (2022). Melatonin is a potential target for improving horticultural crop resistance to abiotic stress. Sci Hortic 291, 110560.

67. Zhao C, Zhang H, Song C, Zhu J, Shabala S (2020). Mechanisms of plant responses and adaptation to soil salinity. Innov 1, 100017.

Figures
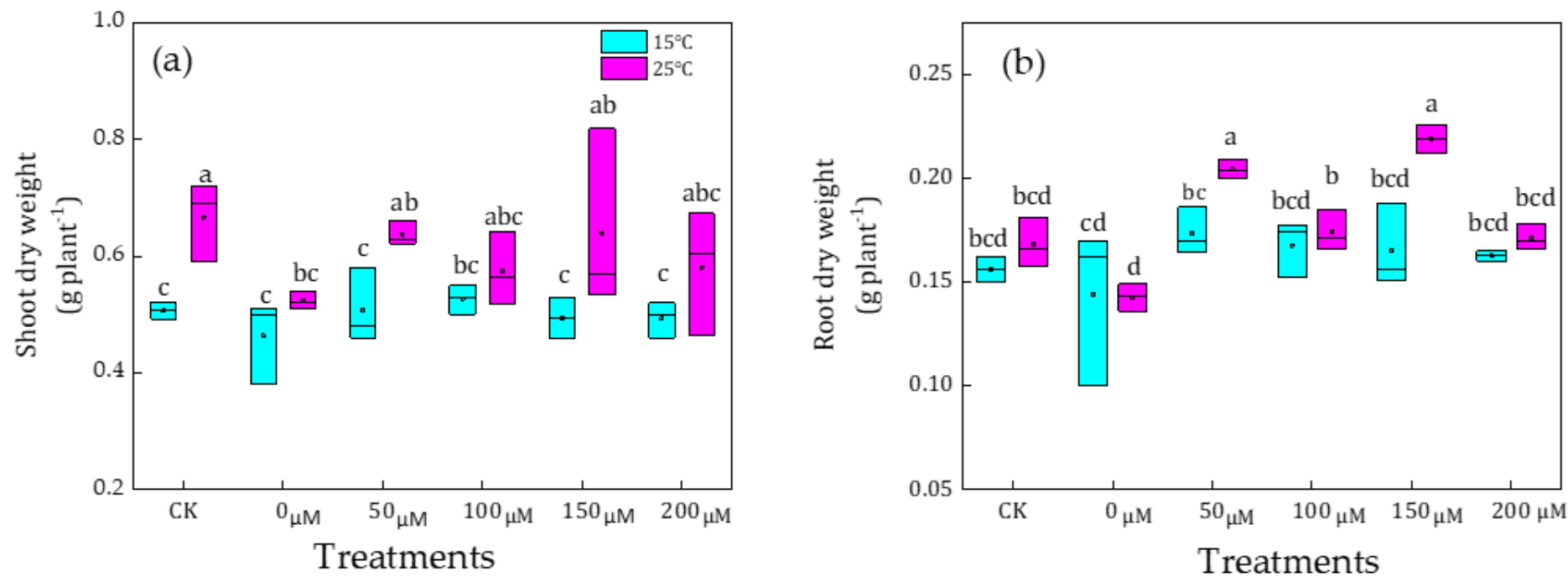

Figure 1

Effects of exogenous melatonin (MT) on (a) shoot dry weight and (b) root dry weight of $150 \mathrm{mM} \mathrm{NaCl}$-stressed cotton seedlings under lowtemperature of $15^{\circ} \mathrm{C}$. Values are means \pm standard deviation $(n=3)$. Different letters represent significant differences at $P<0.05$. 

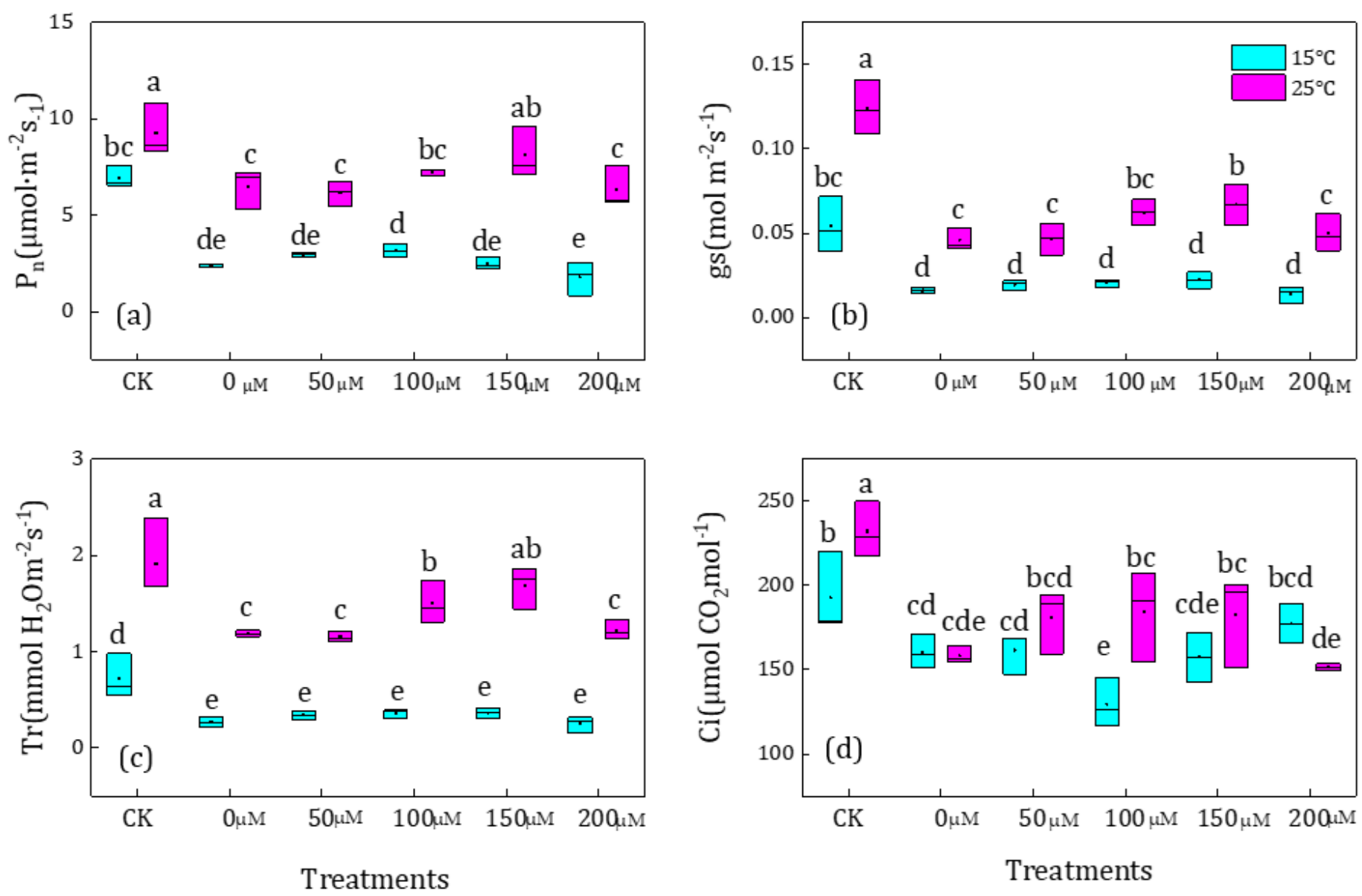

\section{Figure 2}

Effects of exogenous melatonin (MT) on (a) net photosynthetic (Pn), (b) stomatal conductance(gs), (c) transpiration rate (Tr), and (d) intracellular $\mathrm{CO} 2$ concentration (Ci) of cotton seedlings under the condition of $150 \mathrm{mM} \mathrm{NaCl}$ and low-temperature of $15^{\circ} \mathrm{C}$. Values are means \pm standard deviation $(n=3)$. Different letters represent significant differences at $P<0.05$.

(a)

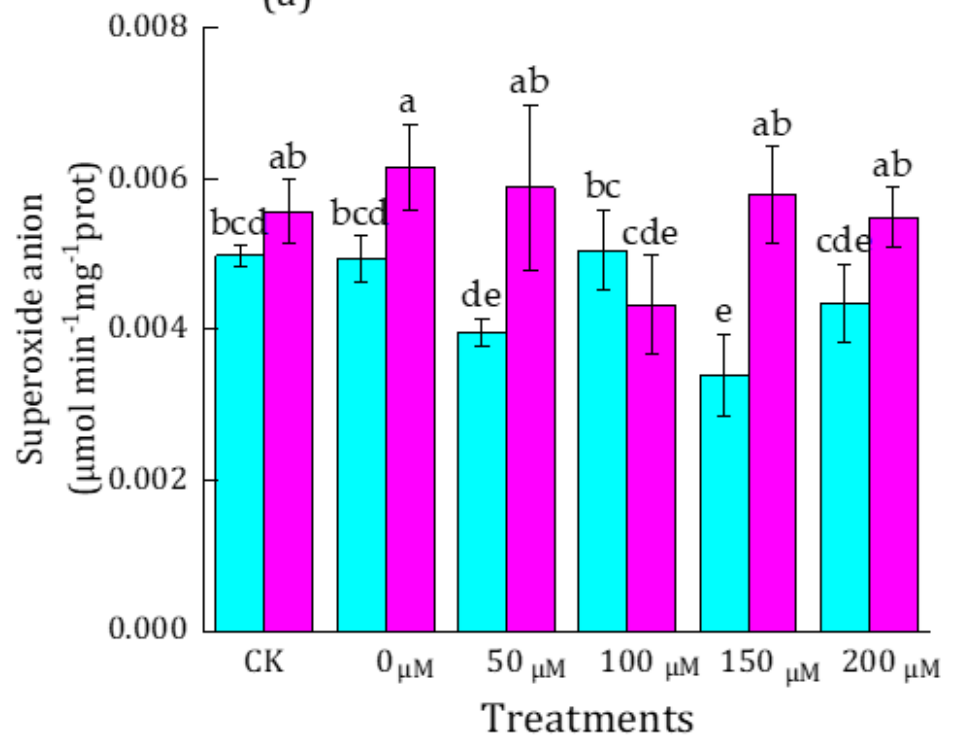

(b)

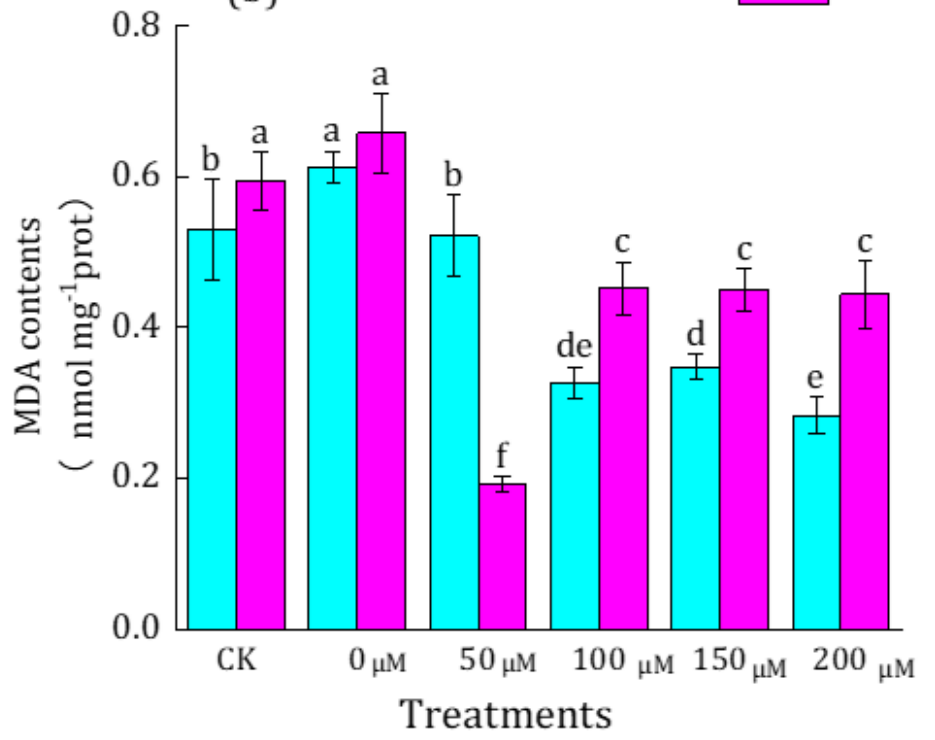


Figure 3

Effects of exogenous Melatonin (MT) on (a) Superoxide anion and (b) malondialdehyde (MDA) of cotton seedlings under 150 mM NaClstressed and low-temperature condition. Values are means \pm standard deviation $(n=3)$. Different letters represent significant differences at $P$ $<0.05$.

(a)
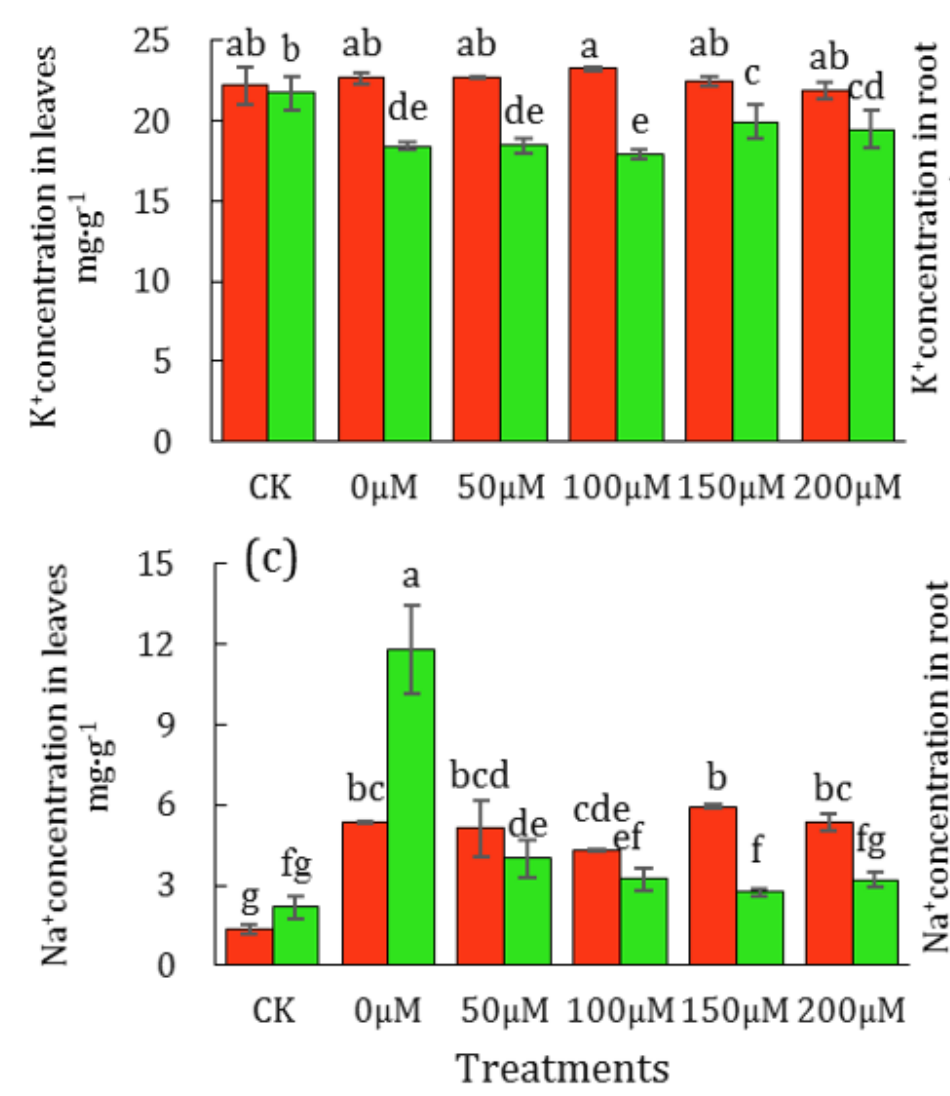

(b)
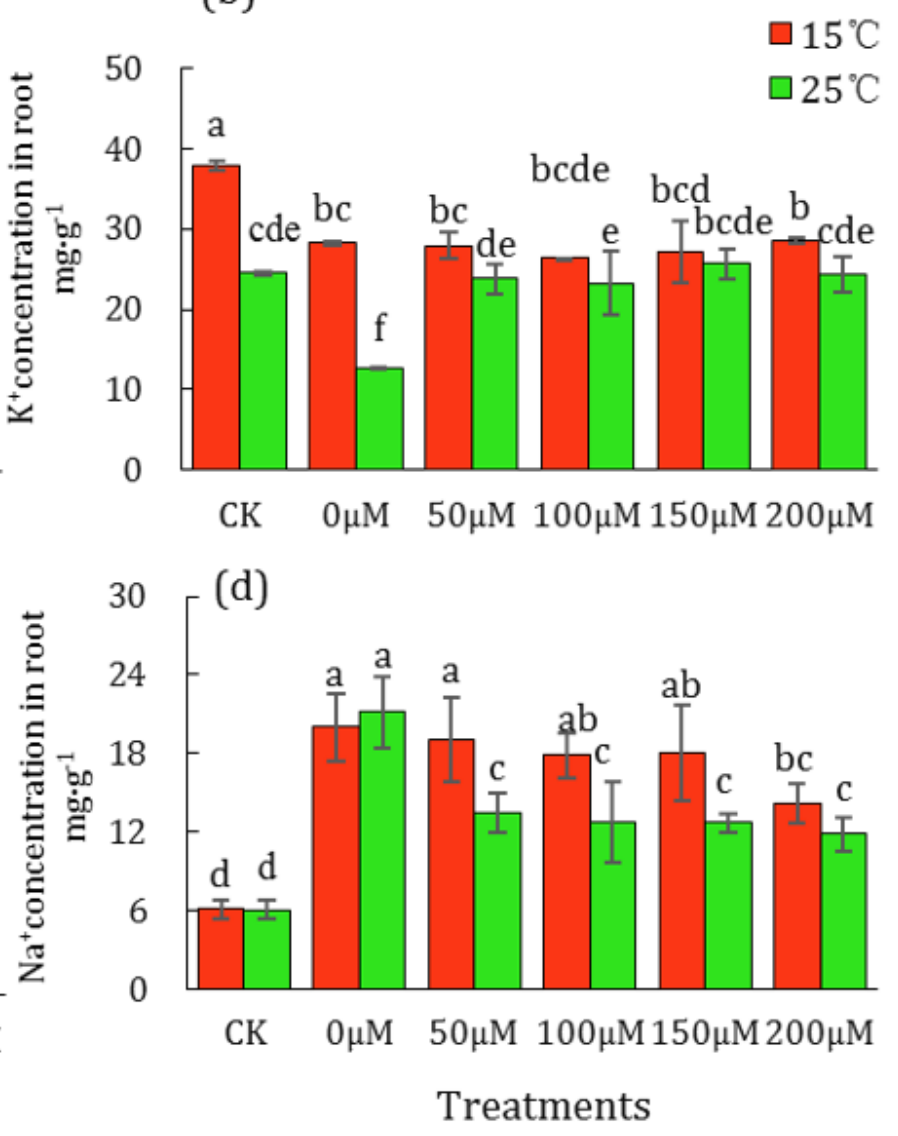

\section{Figure 4}

Effects of exogenous Melatonin (MT) on (a) $\mathrm{K}+$ concentration in the leaves, (b) $\mathrm{K}+$ concentration in the roots, (c) Na+ concentration in the leaves, and (d) $\mathrm{Na}+$ concentration in the roots of cotton seedlings under the $150 \mathrm{mM} \mathrm{NaCl}$-stressed and low-temperature conditions. Values are means \pm standard deviation $(n=3)$. Different letters represent significant differences at $P<0.05$. 


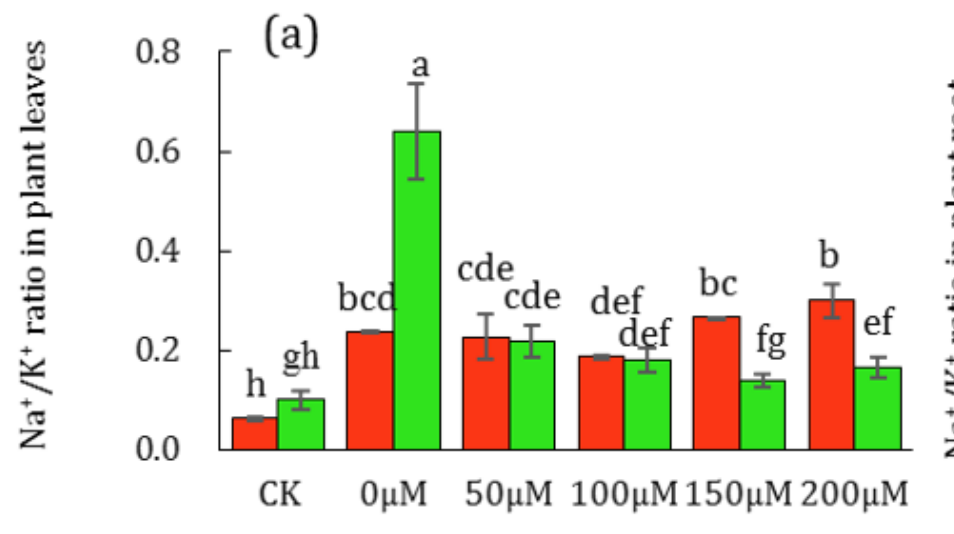

(b)

$\square 15^{\circ} \mathrm{C}$
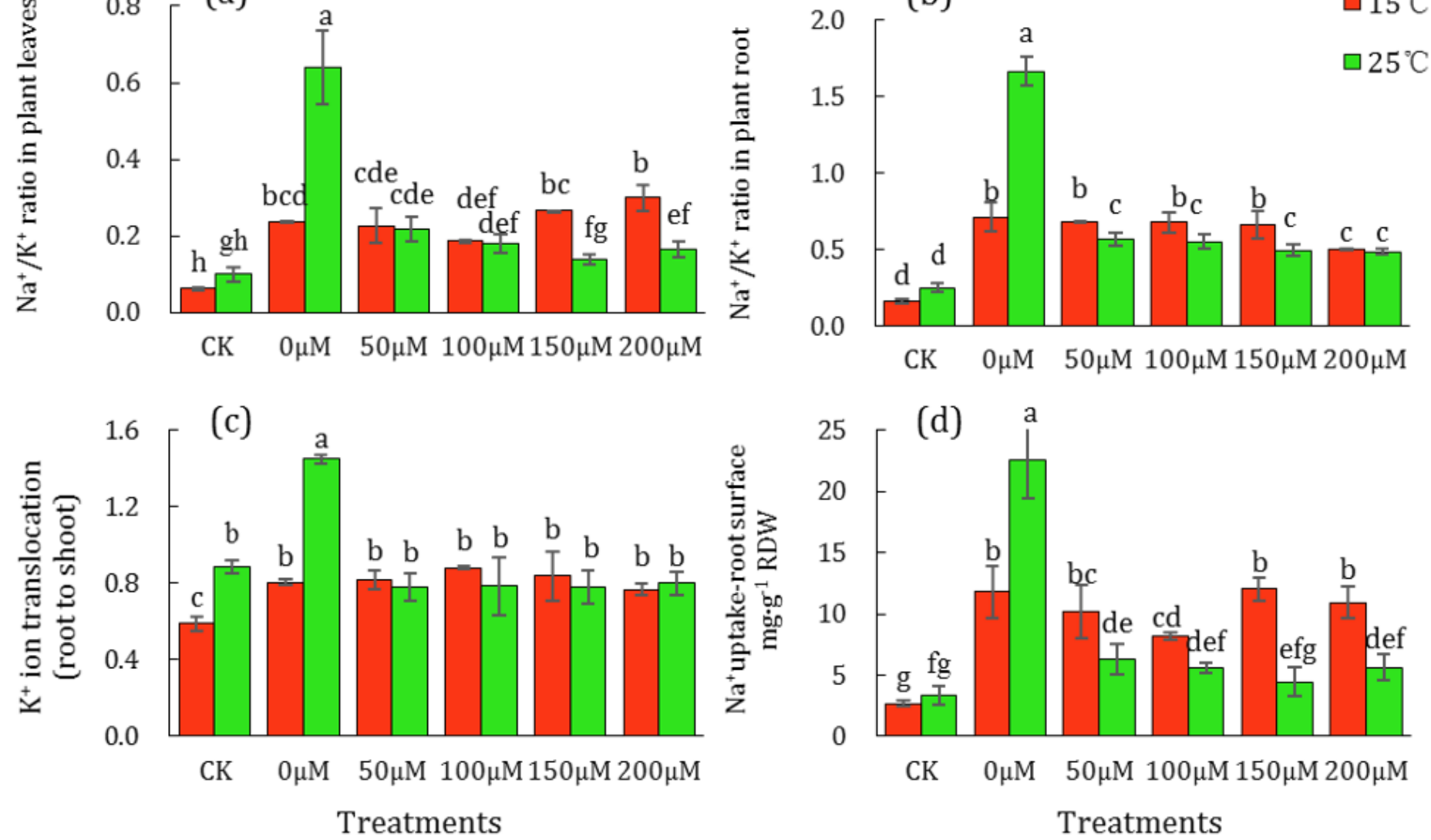

Figure 5

Effects of exogenous Melatonin (MT) on (a) $\mathrm{Na}+/ \mathrm{K}+$ ratio in plant leaves, (b) $\mathrm{Na}+/ \mathrm{K}+$ ratio in plant roots, (c) $\mathrm{K}+$ ion translocation (root to shoot), and (d) $\mathrm{Na}+$ uptake in-root surface of cotton seedlings under the $150 \mathrm{mM} \mathrm{NaCl}$-stressed and low-temperature condition. Values are means \pm standard deviation $(n=3)$. Different letters represent significant differences at $P<0.05$.

(a)

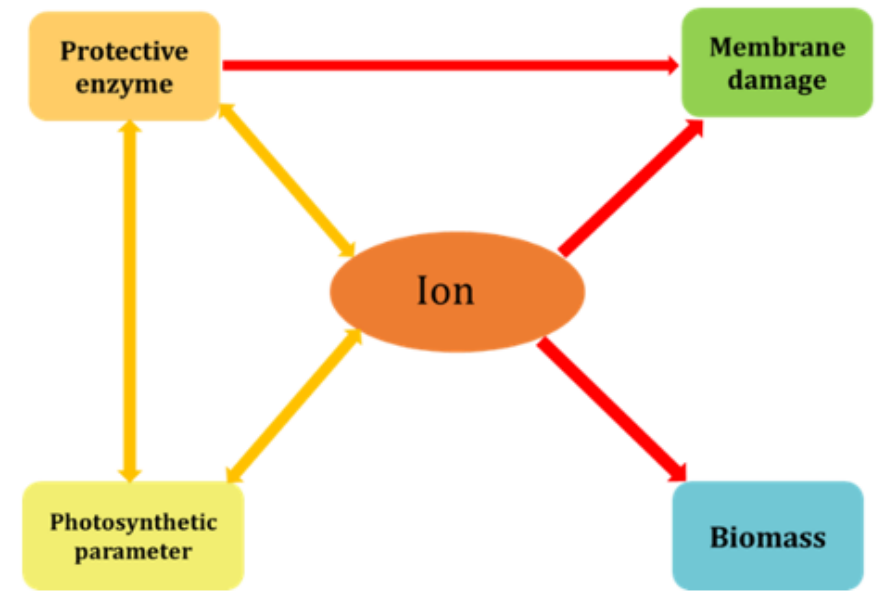

(b)

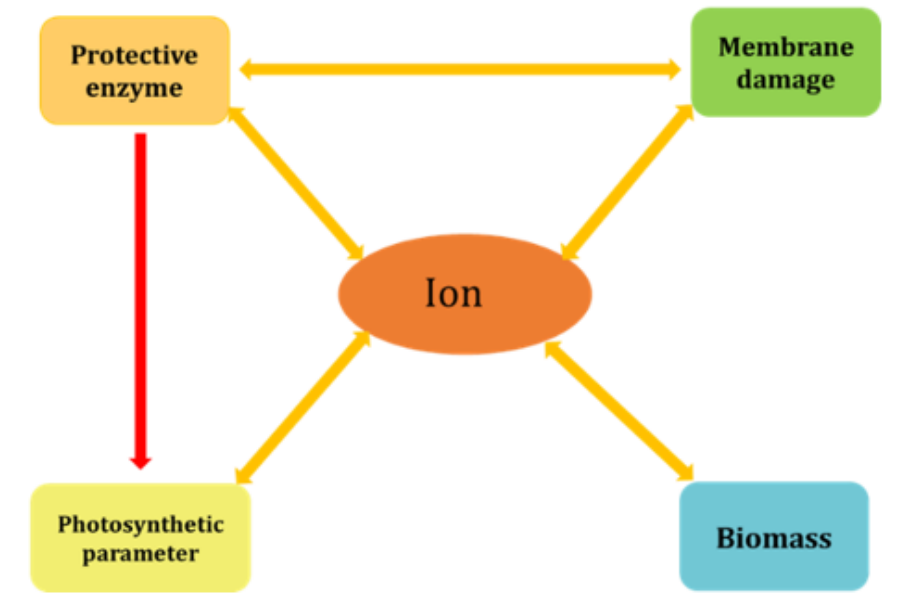

\section{Figure 6}

Effects of exogenous MT on the physiological mechanism of cotton seedlings under (a) salt stress and (b) under coupled low temperature and salt stress. Yellow double orientation arrow indicates that the two affect each other; the red one-way arrow indicates unilateral influence pointing. 

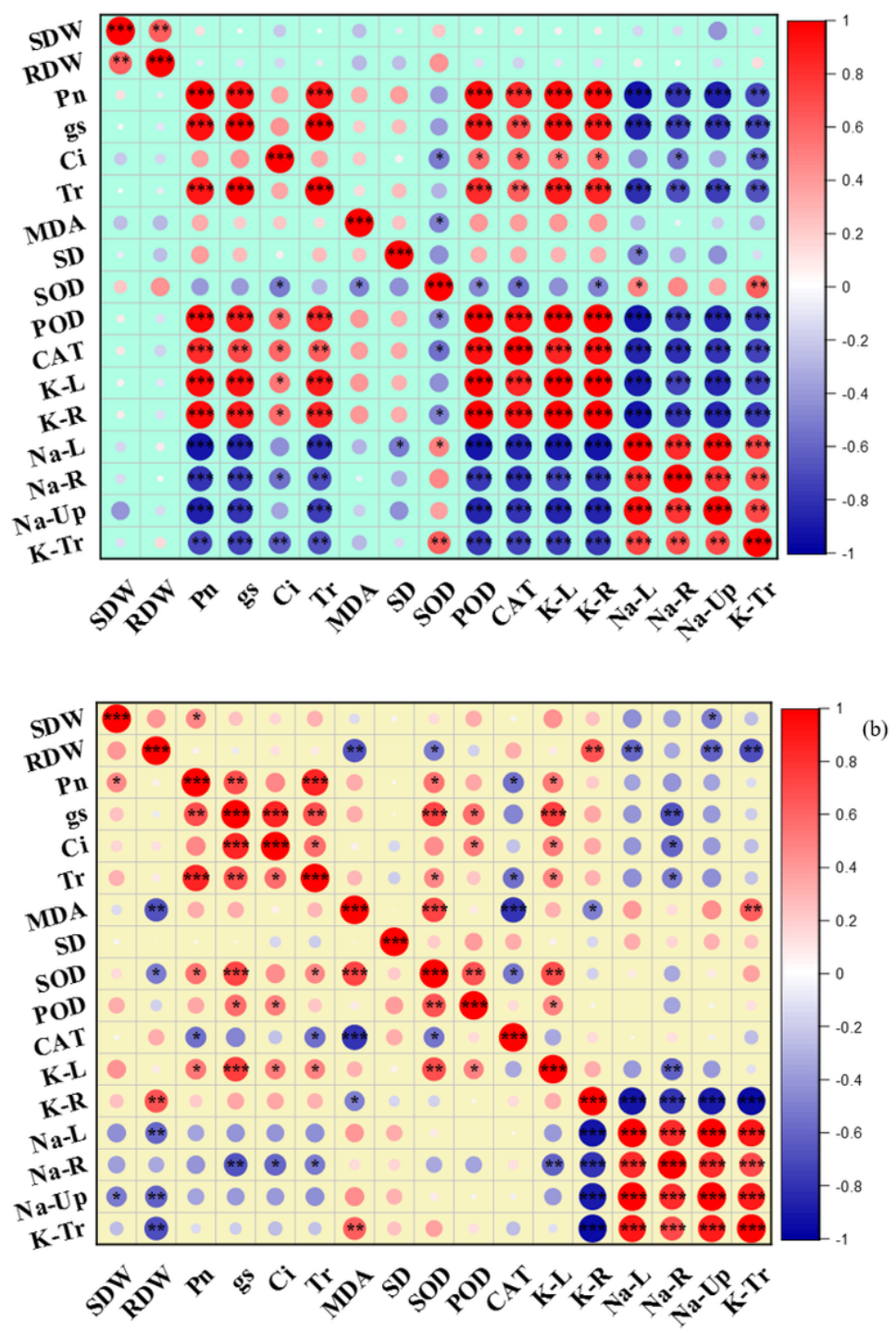

Figure 7

Correlation analysis of exogenous MT on various parameters of salt-stressed cotton seedlings under (a) low temperature $\left(15^{\circ} \mathrm{C}\right)$ and $(\mathrm{b})$ $25^{\circ} \mathrm{C}$. SDW, shoot dry weight; RDW, root dry weight, $\mathrm{Pn}$, net photosynthetic rate; gs, stomatal conductance; $\mathrm{Ci}$, intracellular $\mathrm{CO} 2$ concentration; $\mathrm{Tr}$, transpiration rate; $\mathrm{K}-\mathrm{L}$, leaf $\mathrm{K}+$ content; $\mathrm{K}-\mathrm{R}$, root $\mathrm{K}+$ content; $\mathrm{Na}-\mathrm{L}$, leaf $\mathrm{Na}+$ content; $\mathrm{Na}-\mathrm{R}$, root $\mathrm{Na}+$ content; $\mathrm{Na}+$ uptake; $\mathrm{K}+$ translocation. 